Eberth: Virchow's Archiv, Bd. 65, 1875. Fleury: Thise de Paris, 1886. Fowler: N. Y. Med. Journ., July 3, 1856, p. 7. Freund: Ueher Knochenentzündung in der Reconvalescenz ron Typhus; Breslau. 1885. Friedmann: Berl. klin. Wochensch ritt, 1876, 4, 5, 6. Gamet: Thêse dc Paris, 1862. Garré et Socin: Congré franc. de Chir., 1885, p. 103. Gerdy: Arch. Gén. de Med., 1853; also, Chirurgie pratique, th iii., Paris, 1855. Golay: The de Paris, 1875. Gosselin : Clinique Chir., 1879, i. 165; Archiv. Gen. de MrEd., 1858; article Os, Diet. Jaccoud, xxv. Gouillioud: Thèse de Lyon, 1883. Iranoff: Thise de Puris, 1885. Saboulay: Le Microhe de l'ostco-myélite Aigue; lyon, 1885. Kahlden, ron: Centralhat für Bakteriologie. i. 1887, p. 653 . Kiener et Poulet: Archives de Physiologie. 1883. Klase: Archiv. de Míd., 1858. Kocher: Deutsche Zeitsclurift f. Chir., xi. 1879, pp. 87, 218. Kohls: Deutsehe med. Wochensch., 1887, No. 44, p. 949. Kraske: Verhandl. der Deutselien Gesel. f. Chir., xv. 1886, p. 243; Archiv f. klin. Chir, xxxiv. p. 701. Krause: Fortschritt der Med., 1884, Nos. 7 and 8. Lagrange: Thise de Paris, 1880. Lannelongue el Comby: Arch. gén. de Mred., 1879. Lannelongue: De losteo-myélite Aiguẻ pendant la Croissnnce; Paris, 1879; Bull. et Mrem. de la Soc. de Chir., 1886, sii. p. 474. Lemoyne: Thuse de Paris, 1885. Lüllert: Der Staphylococcus und der Ostcomyelitiscoccus; Würzhurg, 1886. Jücke: Zeitschrift f. Chir, iv. 1874, p. 239. Mereiter: Rev. Mens., 1879. Mläller: Zeitsehrift f. Chir, xxi. Hit. 5 and 6. N. Y. Surg. Soc. Dirrussinn: Philadelphia Medical News, June, 1885, p. 637. Nicaise: Bull. de la Soc. de Chir., 1881. Ogston: Journ. Anat. and Physiol., 1882, xvii. p. 47 Olier: Iev, Mren*, de Med. et de Chir., 1881 ; Discussion: Con. Grès fraç. de Chir., i. 1885, p. 107; Rev. de Chir., 1881. Paget: Clinical Lectures, 1877. Pasteur: Compt. rendus, 1880, p. 1037. Peyroud: Compt. rendus, Oct. 1884. Hanvier: Arch. de Phys., 1863. Reynaud: A rehiv, Gen. de Mlad., 1881. hibberl: Deutsehe med. Wochensebrift, 1884, No. 24. Rodet: Ievue de Chirurgie, 1885, p. 273,636 ; Compt. rendus, 1884, p. 569 . Rondu: The de Paris, 1880. hosenbach: Mikroüranismen bei der Wundinfectionskrankheit des Mensehen; Wieshnden, 1884; Centralblntt f. Chir., $188 \%$, No. 5; 1877, p. 289; Deutsche Zeitsehr. f. Chir., x. 1878, S. 369 . Scheuerlen: Arehiv f. klin. Cliir., xxxii. p. 500. Schlange: Arheiten aus der Chirurgiselsen Kliuik d. Königl. Univ. Berlin, 2te Theil, 1886, S. 93. Schület: Centralhl. f. Chic., 1881. No. 12. Schuteenberger: 'Gaz Mled. ds Strashurg, 1853. Senn: Trans. Anier. Surg. Assoc., 1888. Senny: Thise de Paris, 1870. Socin: Congrès frunc. de Chir., i. 1885, p. 103. Spillmann: Arch. gen. de Mred., 1873. Struck: Deutsehe med. Wochensehrift, 1883, No.46. Thkahas: Ynaug. Dissert., Strassburg, 1887. Thellier: Thise de Paris, 1883. Thelen : Archiv f. Llin. Chir, xxxviii. 212. Trelal: Congrès franc. de Cair., 1885; Progres Méd., 1885, pp. 435, 479. Verneuil: Bull. de ln Soc. de Chir., 1884; Gaz. Med. de Paris, 1852; Revue de Chir., 1883, p.921. Volkmann: Virchow-Hirsel Jahresbericht, 1868 , ii. p. 368 .

\title{
CONGENITAL TUBERCULAR MESENTERIC DISEASE AND SUB-DIAPHRAGMATIC ABSCESS.
}

\author{
By Sayuel Clarke Nonle, M.R.C.S. ExG., L.8.A., \\ OF KENDAL, WETTXOEKLAND, ENOLAXD.
}

THE compnrative infrequency with which congenital diseases, other than syphilitic, are found, and the dificulty so often experienced in discovering in a subiect so young the exnct nnture of any nilment from which it is suffering, and, in crse of a fatal termination, in obtaining an vor. 98, xo. 1.-JULT, 1859. 
autopsy to eonfirm the correctncess or otherwise of any dingnosis made during life, nake a case sueh as that about to be reeorded of peculiar interest.

N. B., female, was geen by me when it ras twenty-eight days old. The ehild lad from its birth been extremely restless, never sleeping at any time for a loager period than half an lour. The mother had eatirely fed the ehild for the first three weeks, but after that time cow's milk, diluted with water, had heen suhstituted oa aecouat of an opinion haviag beea formed by those nursing it that the inaternal supply disagreed. That helicf was fouaded on the fact that the elild's motions were in rariably hard, greenisb, and eurdy, uad that flatulency was rery trouhlesome. The belly bad from birth heen tumid, hut this had heen attrihuted to the presence of $\Omega$ large nmount of flatus; for, wheuever the child eried or appeared in paia, frietioa over the ahdomen seemed to relicve it, and flatus escaped. Castor-oil, dill-water, and lime-water had occasioanlly beea given to relieve symptoms, but still the eoadition of unrest persisted.

When first geen the most aoticeable feature tras tlie great distention of the belly; it was uaiversally tympaaitie, uad the tension so great that it was impossible to map vut with any aeeuracy the position of any of the iateraal organs, or to explore its cavity. Tlie only points disevieruble were the presence of a little more fulaess and resistanec to touch in the right hypochondriae region, and the manifestation of more pain there than elsewhere in palpation. There was no ealargetaent of the superfieial reias, and no rise of temperature. The motions were unhealtly ia eharaeter, and for about twelve lours had been somerhat izatery, but there was no sedinieut of shreddy matter, or traces of bloodelot. There had been no siekness exeept on one pecasion; thic tongue was elean and moist, and food (diluted milk with lime water added) was takea readily.

In the eourse of a week the belly became enormonsly swollen, pereussion eliciting a tympanitie sound; the supertieinl vcins were prominently visible, and there appeared at the navel a fuint blusl of rednes; there was ao fluetuation. The motions were now muel more liealthy and aot loose, aud a snftiejency of bile was preseat in them; but some pain was usually manifested betore the passage of either fatus or stool.

During the ncxt fortaight the umbilieus becane swollen, its redness inereased, and some superfieial fuetuation was detected immediately helow it; the ehild exhihited ao paia in palpation unless pressure was made on the right side ia liver region. Food was taken with iacreasing diffieulty, and pallor, aeeompaaied by wasting, was appnreat. At this time (tbe ehild beiag fifty-oae days old), while nn examination of the ahdomea was bcing mude, pus oozed out at thc garel, and, on pressure, three ouaees were evacuated, ereamy and laudahle in eharacter, and three ounsees were evacuated, ereamy and luring the day ahout one ounee more. After this dis. eharge there was suhsidcnee of the swelliag helow, hut not ahove, the umbilieus, and the blueness of tbe superficial reins became less; hut pain was still evideaced on pressure in tbe rigbt hypochondrium, and glight hut trasicnt strahismus was observed. The ebild's eoadition underwent ao umelionation; food was admiaistered with mucb difficulty ; pallor inereascd; very little sleep wns obtained, and, after the lapse of thres days from the bursting of the ahseess, deatl easued, a eoavulsioa 
having occurred an hour previously. The child at denth was fifty-four days old.

On making a post-mortem exnmination there was found on the right side benenth the peritoneum $n$ large suh-diaphragmatic abscess, containing nearly three ounces of pus, wbicb had hurrowed down thence to the umhilicus, between the peritoneum nnd the deep surface of the ahdomiual muscles. The parietal layer of the peritoneum on the right side was much thickened. The root of the mesentery was invaded with caseated glands, and there rere numerous enlarged glands alung ita attached border. The internal organs were all healthy, and there was no lymph coating the intestines.

The occurrence of tuhercular mesenteric disense and sub-diaphragmatic abscess in a child a month old is prohahly without precedent. The history, howcrer, of this case appenrs to show that the disense was congenital, and that the child nt its birth had either the ahscess commencing or, at any rate, caseous mesenteric glands. That supposition receives confirmation from the fact of there having been persistent unrest, colicky paias, unlsealth motions, aud tumid bclly observed from the very earliest neriod of its existence.

Dr. Eustace Smitb (Disease in Children), in referring to the serofulous diatbesis, states that " a cbild who has the..misfortune to be born uitb"this unhappy predisposition.is liable to very :widespread evideaces of tbe constitutional fault with which he is burdencd. . . . These manifestations of the constitutional tendency usually take place early. . . . Infuats, indeed, are in a great measure exempt from its attacks; but after the "third year it begins to be common." The same author (Wasting Diseases of Children) furtber writes: "setting aside the geaeral rarity of mesenteric disease, and its cxtreme rarity in cbildren under three ycars of age. . . ." Dr. Angel Money (Diseases of Children), in describing tubercular abdominal disease, states that "the child is. usually in the second period of dentition." Dr. Wood (Practice of; Mfedlcine), in his article on disense of the mesenteric.glands, writes:i "This disease is confincd to no period of life, baving been observed in: the fetus of six or seven months, and in old age; but it is most common. iu childbood. By fiur the largest proportion of cases occur between the : ages of one and ten years."

Dr. Ashhy, of Mauchester, who saw the cnse in consultation with me, montioned that the youngest child he lad seeen witb an abdomiual nbscess, the result of tubercular peritonitis and mesenteric disease, was four years old.

Mesenteric disease appenrs to he $n$ little more common in girls than in hoys. Guessent states that, in the Hopital des Enfants at Paris, where no one is admitted under one year or over sixteen, the proportion. of tubcrcular mesenteric cases to the wbole number of deaths may be, 
for hoys, five or six, for girls, six or eight per cent. (Dict. de Mfed., vi. 436).

With regard to the case here reported. none of the symptoms displayed during the first month necessarily characterized mesenteric disease; they were such as might he ascrihable to flatulent distention arising from functional derangement of the stomach or bowels, or both. On this point Dr. Eustace Smith (Introduction to Wasting Diseases of Childhood) writes: "The large size of the helly in wenkly children often attracts the attention of parents, and excites much naxiety. It is most commonly produced hy accumulation of fintus, owing to the weakness of the abdominal walls." And again, "Distention of the nhdomen is by no means n necessary consequence of this disease (tahes mesentericn). On the contrary, unless the glnndular disease be great, the abdominal wall is more often retracted than expanded. It may hecome ocensionally distended from tlatus, as in all crses where the bowels are disordered, but the distention is, in euch cases, independent of the affection of the glands, and is merely un nccidental complication. . - . In all cases, therefore, when the belly is swollen uniformly, the prohahilities are very strongly against meseateric disease; and if no tumor can be detected on pressure in the situation of the glnnds, no foundation cxists for attribu. ting the enlargement of the nhomen to this cause."

Dr. West (Diseases of Infancy and Childhood) writes, "When the digestivo organs perform their functions ill, nothing is more common than for the ahdomen greatly to exceed its natural sizc."

At birth, and until a fortnight hefore death, the child's nutrition was not materially impaired, and it did not look ill. Dr. Eustace Smith (Wasting Dieases of Children), under caseation of mesenteric glands, states that "in cases where the disense is moderate in amount, aud is confined entirely to the glands of the mesentery without heing complicated hy any chrooic lesion of the bowcls, nutrition may he little, if at all, affected. The child may show a fair nmount of flesh; his spirits and appetite mas be good; his temperature patural, aud with the exception, perhnps, of a slight want of color, there may he little in his nppearance to suggest a suspicion of ill bealth." It was only when the distention of the helly hecame so mnrked, nnd the superficial veios so virihle, that grave suspicion arose as to the presence of mesenteric disease. On this point Dr. Eustace Snith, ia the same work, remarks: "If this renous dilatation be very marked, the superficial veins being distinctly seen to ramify upon the nhdominnl wall, and to join the reins of the chest-wall, enlargement of the mesenteric glands should nlways be suspected, in the ahsence of chronic peritonitis or disease of the liver, hut notlling more than suspicion is allowed hy such evidence."

In many cases of tuhcrcular disease of the mesentery, the symptoms are rery amhiguous, and there is diffeulty in detecting hy palpation 
that which is the most relinhle indication of its presence-viz., the existence of enlnrged glands or nodulnr masses, on necount of their depth.

Dr. West (Diseases of Infancy and Childhood) writes: "There is no synptom pathognomonic of tuberele of the mesenteric glnnds, except their heing perceptible through the nbdominnl pnrietes." In this ease, the difficulty of diagnosis was rendered exceptionally great from two causes: first, the very enrly nfre of the elild; second, the extreme tension of the nhdomeu from tympnnites. As to the first, peritonitis was mueb more likely to have existed than tuhereulnr disease, on necount of its greater fregrieney in early infuney. In Owen's Surgical Diseases of Children, the following pangraph from Ziemssen's Cyelopadia, vol. viii., nppesine: "In 186 enses of peritonitis in ehildren, 102 oceurred within the first fortnight, 63 in the third nnd fourth weeks, nnd 15 were over a montb old." In this case, however, the relief afforded by friction-wbich was well horne - and the nhsence of nn elevated temperature negatived the supposition of peritonitis.

Dernme lins described $n$ case of tuherculnr disease of the intestine in nn infnnt twenty-nine dnys old. As to the second, there nre otber disenses which migbt have occssioned the enlnrged belly. Dr. Gnodhart (Diseases of Children) mentions that hoth Hillier nad Rilliet and Bnrthez allude to eases in which cnneer of the nbdominal viscera caused some diffieulty in diagnosis -one in tbe-panereas, the others. in the kidney. Ee also states that lnrge tumors of the kidney are not uncomron. Dr. Eustnce Smith, too (Wasting Diseases of Children), writes: "The liver and spleen may be themselves enlnrged; and grent masses of cnncer occasionnlly spring from the kidney nnd from the otber nbdominal nrgnus."

An exnminntion of some of the eymptoms observed, but obscure, during the life of the child, was nfforded by the situntion in which the abscess was found, as, for exnmple, tbe persistency with wbicb pain was evidenced when pressure was made in the right hypochondrine region, the suhsidence of awelling below, and not nbove, the umbilieus nfter the escnpe of pus; for it is reasonnhle to nssume that nn immense abseess, such as this unquestionably was, interposed between the dinpbrngm nnd the liver, would foree down the Intter orgnn, nnd that when n Inrge qunntity of its eontents was libernted the liver would ngain resume its normal position, nad thus tension helow tbe nnvel would he lessened.

As to the cause of the disense in this case, no evidence of constitutional disease was exhihited in either of the parents. The mother, during the whole period of gestation, was remarkahly healthy and well nourisbed. There was, bowever, $\mathbf{n}$ not very elear bistory of tuherele in the family, nlthough a cousin of the child was known to bnve enlargement of the cervicnl glands. 